\title{
Febrile Seizures: Current Views and Investigations
}

\author{
Aylin Y. Reid, Michael A. Galic, G. Campbell Teskey, Quentin J. Pittman
}

\begin{abstract}
Febrile seizures (FSs) are seizures that occur during fever, usually at the time of a cold or flu, and represent the most common cause of seizures in the pediatric population. Up to $5 \%$ of children between the ages of six months and five years-of-age will experience a FS. Clinically these seizures are categorized as benign events with little impact on the growth and development of the child. However, studies have linked the occurrence of FSs to an increased risk of developing adult epileptic disorders. There are many unanswered questions about FSs, such as the mechanism of their generation, the longterm effects of these seizures, and their role in epileptogenesis. Answers are beginning to emerge based on results from animal studies. This review summarizes the current literature on animal models of FSs, mechanisms underlying the seizures, and functional, structural, and molecular changes that may result from them.
\end{abstract}

RÉSUMÉ: Connaissances actuelles et recherche sur les convulsions fébriles. Les convulsions fébriles (CF) sont des crises convulsives qui surviennent au cours d'un épisode fébrile, habituellement au moment d'un rhume ou d'une grippe. Il s'agit de la cause la plus fréquente de crises convulsives dans la population d'âge pédiatrique. Environ 5\% des enfants âgés de 6 mois à 5 ans présenteront un épisode de CF. Au point de vue clinique, ces crises convulsives sont classifiées comme étant des événements bénins et ont peu d'impact sur la croissance et le développement de l'enfant. Cependant, des études ont établi un lien entre les CF et un risque accru de développer de l'épilepsie à l'âge adulte. Plusieurs questions demeurent sans réponse : quel est le mécanisme sous-jacent; quels sont les effets à long terme de ces crises et quel est leur rôle dans l'épileptogenèse? Des réponses commencent à émerger des résultats d'études animales. Cette revue résume sommairement la littérature actuelle sur les modèles animaux de CF, les mécanismes sous-jacents et les changements fonctionnels, structuraux et moléculaires qui peuvent en résulter.

Can. J. Neurol. Sci. 2009; 36: 679-686

Febrile seizures (FSs) are acute symptomatic seizures that occur in response to a fever in an age-specific manner ${ }^{1,2}$. In the pediatric population, FSs are the most common neurological events, affecting between 2 and $14 \%$ of children worldwide ${ }^{3}$. Retrospective studies have shown that up to $70 \%$ of patients undergoing surgery for treatment-resistant temporal lobe epilepsy (TLE) have a history of FSs in childhood ${ }^{4,5}$. However, prospective analyses have failed to support such a profound relationship, and maintain that FSs are relatively benign events $^{2,6}$. These conflicting reports have created some controversy over the long-term effects of FS. In this context, it is important to identify the types of FSs and recognize that each type may differentially contribute to an increased risk for TLE. Epidemiologic studies indicate that simple FSs, which are generalized seizures with a duration of less than 10-15 minutes, normally do not lead to adverse long-term sequelae ${ }^{7}$. However, complex FSs, defined as focal, prolonged (>30 minutes) or repetitive seizures, appear to be associated with negative longterm consequences ${ }^{8}$. Therefore many experimental investigations have aimed to model complex FS to increase our knowledge of the underlying propensity for, and mechanisms of FSs in order to systemically evaluate the risk for subsequent epileptic disorders.

\section{Animal Models \\ Age-Appropriate Models}

Febrile seizures usually occur in children between the ages of six months and five years-of-age, with a peak incidence around

\footnotetext{
From the Epilepsy \& Brain Circuits Program and Hotchkiss Brain Institute, Departments of Neuroscience (AYR, MAG), Cell Biology and Anatomy(AYR, GCT), Physiology \& Pharmacology (AYR, MAG, QJP), Clinical Neuroscience (AYR), University of Calgary, Calgary, Alberta, Canada.

Received April 20, 2009. Final Revisions Submitted June 23, 2009. Correspondence to: Aylin Y. Reid, Hotchkiss Brain Institute, Epilepsy \& Brain Circuits Program, Department of Physiology \& Pharmacology, Faculty of Medicine, University of Calgary, Health Sciences Centre, 3330 Hospital Dr. N.W., Calgary, Alberta, T2N 4N1, Canada.
} 
1.5 years of age $\mathrm{e}^{1,2}$. Therefore, one of the first requisites of an animal model of FSs must be that the seizures are induced in an animal at a similar developmental stage. Unfortunately, it is difficult to correlate the timing of brain development in humans and rodents, as different aspects of the nervous system do not develop at the same rate in both species. Since the hippocampus is a particular area of interest in FS research, most animal models are induced at an age mimicking the time when important milestones in hippocampal development take place. The second postnatal week in rat development is thought to correspond to the first year of human life, while the third postnatal week might correlate with the toddler years ${ }^{9}$. In most animal models, FSs are induced as early as postnatal day $(\mathrm{P}) 7$ to as late as P16. There is evidence that a FS which occurs in the first year of human life has different outcomes than one occurring later ${ }^{10,11}$, so interpretation of experimental FS studies must take into account the animal's age at time of FS.

\section{Hyperthermic Seizures}

For many decades the study of FSs has focused largely on the role of body temperature ${ }^{12-14}$, which has resulted in the development of several animal models where exogenous heat is used to raise core body temperature (hyperthermia) and produce convulsions ${ }^{15}$. Some models of hyperthermic seizures (HSs) use heat from a hair dryer ${ }^{12}$, a microwave ${ }^{16}$, hot water $^{17}$, or an infrared heat lamp ${ }^{13}$ to increase body temperature to around $41^{\circ} \mathrm{C}$ to generate seizures. While these are relatively simple and effective ways to induce a convulsion, it is not reflective of the natural course of physiological (febrile) responses to a pathogen ${ }^{18,19}$. Hyperthermia is an increase in body temperature that results from excessive exogenous heat application that exceeds the body's capacity for thermoneutrality. Conversely, fever is an endogenous process that comprises a regulated rise in body temperature in response to an immune challenge $\mathrm{e}^{20-22}$. The pathways activated to evoke fever and hyperthermia are different in each case ${ }^{23}$. Fever is also an inflammatory response that involves both central and peripheral cytokine and prostaglandin signalling that is somewhat different from that produced by hyperthermia ${ }^{18,19}$. While this may bring into question the validity of such HS models in the study of "febrile" seizures, these studies cannot be ignored as they have provided significant advances in our knowledge about the mechanisms and sequelae of $\mathrm{FSs}^{24}$.

\section{"Febrile" Seizures}

The Pittman laboratory has developed a novel and more ethologically relevant model of FSs using an inflammatory dose of the bacterial endotoxin lipopolysaccharide (LPS) which evokes an immune reaction and a bona fide fever response (about $1-1.5^{\circ} \mathrm{C}$ ), coupled with what is normally a subconvulsant dose of kainic acid (KA) in immature rats (P14) ${ }^{25-27}$. This model mimics the most essential features of a FS: the immune response and fever; nonetheless, just as the 'hyperthermia' model has drawbacks as indicated above, this model requires augmentation of excitation with KA. The reason that all models employed to date rely on more than just a true fever is that, at least at the ages tested, even in immature common laboratory rat strains FSs are difficult to evoke. Why humans develop true febrile convulsions, whereas immature rodents generally do not is still unknown. Our laboratory has also demonstrated long-term changes in the seizure susceptibility of animals that experienced FSs during development ${ }^{26}$. Currently, the mechanism by which such change takes place is not completely understood; however, considerable data is available indicating that other models of FSs (such as HSs) can modify the brain in such a manner to induce increased susceptibility to seizures in adulthood ${ }^{28-30}$.

\section{Mechanisms of Febrile Seizures}

\section{Temperature}

One of the fundamental questions about FSs that remains unanswered is why they develop in some children with a febrile illness but not others. It does not appear to be the magnitude of fever which plays a role. Children with a lower fever at the time of FS have an increased risk for subsequent convulsion with another febrile illness, perhaps because they have a lower threshold for FSs in the first place ${ }^{1,31,32}$. However, as a group, children with a FS present to the emergency department with fever of higher magnitude than febrile controls, suggesting children susceptible to FSs may regulate temperature differently ${ }^{33}$, or that their infections are more severe. Clinically it is very difficult to determine the exact temperature at seizure onset, and sometimes FSs can occur as the presenting sign of febrile illness ${ }^{1}$. While fever is defined as a temperature of at least $38.4^{\circ} \mathrm{C}$, some clinical studies of FSs have accepted temperature values as low as $38^{\circ} \mathrm{C}^{34,35}$, a temperature below that thought to create central nervous system (CNS) dysfunction ${ }^{36}$.

Why should a rise in temperature cause a seizure in the first place? Hyperthermia $\left(>38.3^{\circ} \mathrm{C}\right)$ can decrease gammaaminobutyric acid $\mathrm{A}\left(\mathrm{GABA}_{(\mathrm{A})}\right)$ receptor-mediated inhibition to a greater extent than it decreases excitation, which may shift the balance towards excitation and contribute to seizure generation $^{37}$. This appears to be mediated by reducing GABA release from pre-synaptic terminals, but hyperthermia may also decrease post-synaptic $\mathrm{GABA}_{(\mathrm{A})}$ receptor function ${ }^{38}$. While this phenomenon has only been studied in hyperthermic models, it also likely occurs when temperature is increased from physiologic fever.

Typically children will only have a single FS in the course of a febrile illness. Is the first seizure protective against subsequent seizures? In experimental HSs the temperature threshold for the second or third seizure is significantly and progressively higher than for the first, although this pattern is abolished by a neuropeptide $\mathrm{Y}$ antagonist ${ }^{39}$. It is possible that the typical clinical picture of a single FS in children may involve inhibitory actions of neuropeptide Y, but further work has yet to be done. Likewise, with respect to true FSs, it is important to remember that a number of transmitters and modulators are involved in the febrile process within the brain. Some of these, for example, arginine vasopressin, have been implicated in experimental $\mathrm{FS}^{40}$, but their actions have not been investigated in sufficient detail to comment further.

\section{Inflammatory Mediators}

Cytokines have been shown to play a significant role in a number of neurological disorders ${ }^{41,42}$ including seizures ${ }^{43-46}$. Pro-inflammatory cytokines include tumour necrosis factor 
(TNF) $\alpha$, interleukin (IL)- $1 \alpha$, IL- $1 \beta$, and IL-6 ${ }^{47}$, while IL-1 receptor antagonist (IL-1ra), IL-10, and IL-18 are considered anti-inflammatory ${ }^{48}$. Interleukin- $1 \beta$ can influence seizures by changes to $\mathrm{N}$-methyl-D-aspartate receptor phosphorylation ${ }^{49}$, inhibiting astrocytic reuptake of glutamate ${ }^{50}$, and by increasing the release of glutamate from glia ${ }^{51}$ and neurons ${ }^{52}$, leading to increased excitability. Interleukin- $1 \beta$ also decreases $\operatorname{GABA}_{(\mathrm{A})}$ receptor mediated currents, decreasing inhibition ${ }^{53}$.

Helminen and Vesikari ${ }^{54}$ suggested that an enhanced IL-1 $\beta$ response in children with FS could play a role in the production of seizures. They showed that peripheral mononuclear cells extracted from children with FSs showed a significantly exaggerated IL- $1 \beta$ response to LPS application when compared with samples from children with bacterial infections that did not have seizures ${ }^{54}$. Leukocytes from children with a previous FS also have an exaggerated IL-1 $\beta$ response in a viral infection $\operatorname{model}^{55}$. Specific IL-1 $\beta$ promoter polymorphisms increase IL$1 \beta$ production $^{56}$, and may contribute to genetic susceptibility for $\mathrm{FSs}^{57-60}$, as may IL-1 ra polymorphisms ${ }^{60}$. However, some studies have shown plasma levels of IL-1 $\beta$ are comparable in children with FSs and those with a febrile illness without seizure, suggesting increased production of the cytokine is not involved in the pathogenesis of $\mathrm{FSs}^{61,62}$, and there is no difference in the distribution of IL-1 $\beta$, IL- $1 \alpha$, or IL-1ra genotypes and alleles in children with FS versus healthy controls ${ }^{63}$. While plasma levels may not accurately reflect activity in the brain, these findings are also supported by unchanged levels of IL- $1 \beta^{47,61}$, TNF- $\alpha^{47}$ and IL- $6^{47}$ in the cerebrospinal fluid of children after a FS. However, there is ample evidence from animal experiments that peripheral inflammation, and associated cytokine changes, are reflected by the appearance of a 'mirror' inflammation in the brain, reflected by increases in inflammatory cytokines in the brain ${ }^{64-66}$. Thus, it is quite possible that cerebrospinal fluid levels of cytokines may not accurately reflect parenchymal levels in children with FS.

In addition to a possible role in FSs, CNS inflammation and cytokines also play a role in other age-dependant seizures. The prototypic inflammatory epilepsy is Rasmussen's encephalitis, or chronic focal encephalitis, comprising intractable focal seizures with onset in childhood, progressive hemiparesis, and cognitive impairment. This is accompanied by progressive unilateral cerebral atrophy and inflammatory changes. Approximately half of children with Rasmussen's encephalitis have a preceding infection or inflammatory episode in the six months prior to presentation ${ }^{67}$, although the actual etiology of this disorder is still unknown ${ }^{68-71}$. Interestingly, while inflammation is present, FSs do not occur in the context of this disorder.

Other situations where there is brain inflammation, such as the inflammatory viral encephalitides caused by herpes simplex, Epstein-Barr, and varicella zoster viruses, are characterised by epileptogenic seizures, but not necessarily $\mathrm{FSs}^{72}$. Other agedependant epilepsies, such as benign childhood focal epilepsies (rolandic epilepsy, Panayiotolpoulos syndrome, and idiopathic childhood occipital epilepsy of Gastaut) and generalized epilepsy with febrile seizures plus, are not characterized by an inflammatory state. However, FSs can be highly prevalent in these conditions ${ }^{73-75}$. Therefore, the role of CNS inflammation in seizures and epilepsy in general, and in FSs in particular, is still controversial as the association is not absolute.
While human data appear to be conflicting, animal data reveal a great potential for new immunological treatments and interventions for patients with seizures and epilepsy. Exogenous IL-1 $\beta$ administration to immature mice reduces their threshold for HSs, while mice deficient for the IL- $1 \beta$ receptor are resistant to HSs even in the presence of exogenous IL-1 $\beta^{76}$. In the LPS/KA FS model, rats with a FS showed increased IL-1 $\beta$ levels in the hippocampus and hypothalamus compared with febrile controls, with an increased rate of seizures after intracerebroventricular IL-1 $\beta$ administration, and a decreased seizure rate after IL-1ra administration ${ }^{27}$. While increased excitability in the presence of IL-1 $\beta$ is likely one mechanism promoting FS generation, there is currently a large amount of ongoing work which will hopefully add to our knowledge about the role of cytokines in seizures and epilepsy.

\section{Alkalosis}

Evidence suggests that there is an increased respiratory rate in children with fever 77,78 , although it is unclear whether this actually leads to a respiratory alkalosis. This possible link may be important, as alkalosis increases neuronal excitability ${ }^{79-81}$. Animal HS models cause respiratory alkalosis ${ }^{82,83}$, and suppressing the alkalosis with $\mathrm{CO}_{2}$ administration quickly abolishes HSs and prevents some of the long-term effects found with these models ${ }^{82}$. It is unclear whether this mechanism plays any role in seizure generation in the child with a FS.

\section{The "Double-Hit" Hypothesis}

Apart from FSs, developmental malformations such as focal cortical dysplasias and microdysgenesis have also been implicated in the development of $\mathrm{TLE}^{84}$. Rats with experimental neuronal migration disorders have a lower threshold for HSs, which cause increased neuronal damage compared to HS alone ${ }^{85}$. In an animal model of focal cortical lesion plus HSs there is a lowered threshold for the HSs and prolonged ictal manifestations ${ }^{86}$, with animals displaying impaired performance on the Morris water maze and 80\% developing spontaneous seizures $^{87}$. This model also results in decreased volumes of the whole brain, of the hemisphere ipsilateral to the cortical lesion, and of the hippocampus compared with HSs in non-lesioned animals, resulting in impairment of normal brain development ${ }^{88}$. These results suggest that FSs may have more severe consequences when occurring in a susceptible brain which has already seen some form of injury.

\section{Consequences of Febrile Seizures}

\section{Functional Changes}

There has always been great interest in the risk of developing epilepsy after a FS. In a large population cohort of children from Denmark, those with a history of FS had a greater than five-fold increase in the risk of developing epilepsy later in life, although less than $7 \%$ developed epilepsy within 23 years of follow-up ${ }^{89}$. Camfield and colleagues have found that FSs most often precede the development of generalized tonic-clonic afebrile seizures and rarely idiopathic intractable complex partial seizures ${ }^{90}$. However, others have found a link with epilepsies with complex partial seizures, notably TLE. Retrospective studies have shown that up to $70 \%$ of patients undergoing surgery for treatment- 
resistant TLE have a history of FSs in childhood ${ }^{7,8}$. On the contrary, prospective follow-up studies have found the occurrence of mesial temporal sclerosis is uncommon after FSs ${ }^{91}$ and that while a higher proportion of children with complex FS than simple FS develop subsequent epilepsy, the overall risk is still low ${ }^{2}$.

While the association between FSs and the development of epilepsy is still controversial, there do appear to be differences in patients with TLE who have a history of a FS and those who do not. Adults with TLE and a prior history of FS have poorer seizure control and more resistance to drug therapy ${ }^{92-94}$. On the other hand, these patients have better surgical outcome ${ }^{93,95,96}$.

Just as in human studies, animal studies are conflicted as to whether early-life HSs or FSs lead to the development of epilepsy and spontaneous seizures. Most studies have focused on the development of limbic seizures, to further knowledge about the role of development of TLE after FS in humans. With the HS model spontaneous limbic seizures have been demonstrated in $35 \%$ of animals three months after HS, with interictal epileptiform discharges in $88 \%{ }^{29}$. Animals with spontaneous seizures have increased levels of immunoreactivity of a glutamate transporter in the dentate gyrus, and immunoreactivity for markers of interneurons in the hilus ${ }^{97}$. Studies looking at other forms of epilepsy and seizure susceptibility have found repetitive HSs facilitate seizures induced by the chemical convulsant pentylenetetrazol at six months-of-age, but do not affect absence seizures in the genetic WAG/Rij rat model ${ }^{98}$. Electrical kindling studies have revealed lower afterdischarge thresholds and longer afterdischarge durations in adults with previous FS compared with febrile controls, but the amygdala kindling rate was the same ${ }^{26}$. This model appears to alter seizure susceptibility but not epileptogenesis.

Epilepsy is not the sole functional consequence of importance after a FS. Complex FSs may have an effect on global brain development, as patients with epilepsy and a history of complex FS have smaller total cerebral volumes than epileptic patients without complex $\mathrm{FS}^{99}$. However, in school-age children, a history of FS did not have adverse effects on behaviour, scholastic performance, or neurocognitive attention ${ }^{10,100,101}$. In fact, those with previous FS performed significantly and consistently better on tasks of working memory ${ }^{11}$, suggesting intact function of the hippocampi. However, if the FS occurred in the first year of life then the children had deficits in learning, consolidation, and delayed recognition ${ }^{11}$ and required special schooling more often than those with later $\mathrm{FSs}^{10}$. As mentioned earlier, these findings make it very important to take the age of FS into account when interpreting data from animal studies. It is possible that an experimental FS induced at P10, which correlates with a time point within the first year of human life ${ }^{9}$, may lead to very different long-term consequences than a seizure induced at P14, correlating with toddlerhood ${ }^{9}$.

While a single HS at P10 has also been correlated with a hyperanxious phenotype in adulthood ${ }^{102}$, many studies have found no memory deficits in adulthood ${ }^{102-105}$. One study provoking single HSs found significantly more Morris water maze errors in adult rats with previous HS at P5, and to a lesser extent those with $\mathrm{HS}$ at P15 106 . While there is controversy about the long-term sequelae of a single seizure, it seems that repetitive HSs beginning on P10 cause long-term memory deficits, and impaired intermediate and long-term memory in a model whereas a single HS had no effects ${ }^{107}$. These discrepancies may be in part due to age of seizure onset, supported by the findings in humans, but also may be model specific.

\section{Structural Changes}

The most obvious avenue to pursue when looking for mechanisms of epileptogenesis after a FS, particularly in association with TLE, would be structural changes in the limbic system. While magnetic resonance imaging (MRI) is not usually required in the diagnostic work-up of FSs, MRI studies have revealed a great deal about hippocampal changes associated with FSs. In 11 children with MRI studies after febrile status epilepticus, seven had abnormal hippocampal signal intensity within 72 hours post seizure, and five of these children met criteria for mesial temporal sclerosis at follow-up imaging (mean follow-up was nine months), while these changes were not seen in any of the children without initial MRI changes ${ }^{108}$. Children with both focal and prolonged FSs are more likely to have MRI abnormality than those with simple FS, suggesting underlying abnormality may predispose to lowered seizure threshold ${ }^{109}$. Duration of FS has also been linked to hippocampal changes, as more prolonged FS results in larger hippocampal volumes and higher signal intensity within five days ${ }^{110}$. These MRI changes may correlate with edema, but may also be due to structural changes leading to increased predisposition to the later development of epilepsy. Hippocampal asymmetry seen after the resolution of edema may represent a pre-existing hippocampal abnormality predisposing to $\mathrm{FSs}^{111}$. Long-term studies reveal history of a simple FS is associated with decreased hippocampal volume and increased T2 relaxation time in an MRI study greater than 15 years after the FS ${ }^{112}$.

Febrile seizures are for the most part thought not to cause cell death and are still considered benign in children. However, evidence from animal studies indicates structural changes may in fact be occurring, which could lead to long-term consequences. Again, evidence is conflicting and may be model specific. Within HS models in rats, T2 signal enhancement on MRI within the dorsal hippocampus, piriform cortex, or amygdala was seen in $72 \%$ of animals at 24 hours post-HS, and in $87 \%$ of animals at eight days, but there was no evidence of neuronal injury or death $^{113}$. This is consistent with other studies finding no hippocampal cell loss after prolonged $\mathrm{HS}^{29,107,114,115}$ or $\mathrm{FS}^{25}$. However, one study has reported death of up to $60 \%$ of neurons in the CA 1 and CA3 regions of the hippocampus ${ }^{116}$.

While cell death does not occur in all models of HSs or FSs, there appear to be other pathological cellular processes occurring which may promote epileptogenesis. Mossy fibre sprouting has been found in some HS models ${ }^{17,114}$, which may be disrupting the normal circuitry of the limbic system, though again this is not a consistent finding across models ${ }^{107}$. There is also the possibility that limbic system circuitry may also be disrupted by altered neurogenesis after a FS. There is an increase in the number of newly developed granule cells and synaptogenesis in the dentate gyrus six to nine weeks after a $\mathrm{HS}^{97}$, although this may be unique to the male sex ${ }^{117}$. There was no effect on the GABAergic population, but there was less expression of neuronal excitatory amino acid transporter 3, which functions to remove glutamate from the synaptic cleft ${ }^{118}$. This change may also alter the balance 
of excitation within the limbic system, promoting increased seizure susceptibility in later life. However, not all studies have found altered neurogenesis after prolonged HSs ${ }^{114}$.

\section{Molecular Changes}

Structural changes are not the only changes responsible for altered levels of excitability, and given the lack of evidence for substantial structural changes focus has shifted to changes at the molecular level which may alter epileptogenesis after a FS. Hyperpolarisation-activated, cyclic nucleotide-gated (HCN) channels present in neuronal tissue are activated by hyperpolarisation, generating a depolarizing current called $\mathrm{I}_{(\mathrm{h})}{ }^{119,120}$. After a prolonged HS there is a long-lasting enhancement of $I_{(h)}$ which converts potentiated synaptic inhibition to hyperexcitability in an activity-dependant manner ${ }^{121}$. The gene expression of various isoforms of $\mathrm{HCN}$ channels is altered in a cell-specific manner within the hippocampus ${ }^{122}$, with developmental seizures causing a formation of heteromeric channels ${ }^{123}$ and a reduction in the amount of spike broadening in the hippocampus ${ }^{124}$, provoking persistent hippocampal hyperexcitability. These changes in HCN channels appear to be due to the presence of GluR2 subunitlacking AMPA receptors, allowing increased calcium permeability with downstream effects on gene expression ${ }^{125}$.

While alterations to $\mathrm{HCN}$ channels lead to increased excitability, other changes can lead to decreased inhibition. The endocannabinoid system is another important mediator of altered excitability. Hyperthermic seizures cause a selective increase in pre-synaptic inhibitory transmission in GABAergic synapses into adulthood ${ }^{126}$. This is mediated by an increased number of pre-synaptic CB1 receptors, which causes persistent enhancement of activity dependant, retrograde inhibition of GABA release by endogenous cannabinoids in the hippocampus ${ }^{127}$. Hyperthermic seizure models have also been shown to modify binding of GABA and benzodiazepines to the $\mathrm{GABA}_{(\mathrm{A})}$ receptor ${ }^{128}$, and down-regulate $\mathrm{GABA}_{(\mathrm{B})}$ receptor expression ${ }^{129}$, decreasing $\mathrm{GABA}_{(\mathrm{B})}$ receptor-mediated inhibition in the hippocampus ${ }^{130}$. These alterations in inhibition, together with the mechanisms for increased excitability mentioned above, are likely contributing to epileptogenesis seen after HSs.

\section{Conclusions}

While animal models have significantly added to our knowledge of FSs, we must be cautious in our interpretations of these studies. Hyperthermic seizures are not necessarily the best model of FSs, and mechanisms involved in the generation of these types of seizures, such as respiratory alkalosis, may not be applicable to the human condition. Experimental FSs resulting from the administration of LPS and KA do rely on the generation of a true fever, but are still using a chemical convulsant to induce the seizures, which again may make results from this model inapplicable to children with FSs. However, these models have allowed us to make important discoveries about the mechanisms and consequences of FSs. The mechanisms by which FSs are generated appear to involve genetic factors and inflammatory mediators, and may be related to pre-existing abnormalities in the brain. Febrile seizures lead to epilepsy in some models, likely through molecular changes which alter the balance of excitation and inhibition in the limbic system. Cell death does not appear to be required in this form of epileptogenesis. Future studies in both children and animals will hopefully lead to a better understanding of these seizures, so that we can then shift focus towards strategies aimed at preventing epileptogenesis and other undesired consequences of FSs.

\section{ACKNowledgements}

This work was supported by the Canadian Institutes of Health Research (CIHR), Natural Sciences and Engineering Research Council of Canada (NSERC) and personnel awards from CIHR, NSERC, Alberta Heritage Foundation for Medical Research, Hotchkiss Brain Institute, and the Killam Trust.

\section{REFERENCES}

1. Berg AT, Shinnar S, Hauser WA, Alemany M, Shapiro ED, Salomon $\mathrm{ME}$, et al. A prospective study of recurrent febrile seizures. N Engl J Med. 1992; 327:1122-7.

2. Verity CM, Golding J. Risk of epilepsy after febrile convulsions: a national cohort study. BMJ. 1991; 303:1373-6.

3. Hauser,WA. The prevalence and incidence of convulsive disorders in children. Epilepsia. 1994; 35 Suppl 2:S1-6.

4. Nelson KB, Ellenberg JH. Prognosis in children with febrile seizures. Pediatrics. 1978; 61:720-7.

5. Annegers JF, Hauser WA, Shirts SB, Kurland LT. Factors prognostic of unprovoked seizures after febrile convulsions. N Engl J Med. 1987; 316:493-8.

6. Frantzen E, Lennox-Buchthal M, Nygaard A. Longitudinal EEG and clinical study of children with febrile convulsions. Electroencephalogr Clin Neurophysiol. 1968; 24:197-212.

7. Falconer MA, Taylor DC. Surgical treatment of drug-resistant epilepsy due to mesial temporal sclerosis. Etiology and significance. Arch Neurol. 1968; 19:353-1.

8. Lewis DV. Febrile convulsions and mesial temporal sclerosis. Curr Opin Neurol. 1999; 12:197-201.

9. Avishai-Eliner S, Brunson KL, Sandman CA, Baram TZ. Stressedout, or in (utero)? Trends Neurosci. 2002; 25:518-24.

10. Verity CM, Greenwood R, Golding J. Long-term intellectual and behavioral outcomes of children with febrile convulsions. $\mathrm{N}$ Engl J Med. 1998; 338:1723-8.

11. Chang YC, Guo NW, Wang ST, Huang CC, Tsai JJ. Working memory of school-aged children with a history of febrile convulsions: a population study. Neurology. 2001; 57:37-42.

12. Baram TZ, Gerth A, Schultz L. Febrile seizures: an appropriateaged model suitable for long-term studies. Brain Res Dev Brain Res. 1997; 98:265-70.

13. Holtzman D, Obana K, Olson J. Hyperthermia-induced seizures in the rat pup: a model for febrile convulsions in children. Science. 1981; 213:1034-6.

14. Lennox MA, Sibley WA, Zimmerman HM. Fever and febrile convulsions in kittens: a clinical, electroencephalographic, and histopathologic study. J Pediatr. 1954; 45:179-90.

15. Baram TZ, Shinnar S. Febrile seizures. Elsevier. San Diego: Academic Press; 2002.

16. Hjeresen DL, Diaz J. Ontogeny of susceptibility to experimental febrile seizures in rats. Dev Psychobiol. 1988; 21:261-75.

17. Jiang W, Duong TM, de Lanerolle NC. The neuropathology of hyperthermic seizures in the rat. Epilepsia. 1999; 40:5-19.

18. Berg AT. Are febrile seizures provoked by a rapid rise in temperature? Am J Dis Child. 1993; 147:1101-3.

19. Ostberg JR, Taylor SL, Baumann H, Repasky EA. Regulatory effects of fever-range whole-body hyperthermia on the LPSinduced acute inflammatory response. J Leukoc Biol. 2000; 68:815-20.

20. Elmquist JK, Scammell TE, Saper CB. Mechanisms of CNS response to systemic immune challenge: the febrile response. Trends Neurosci. 1997; 20:565-70. 
21. Saper CB. Neurobiological basis of fever. Ann N Y Acad Sci. 1998; 856:90-4.

22. van Dam AM, Poole S, Schultzberg M, Zavala F, Tilders FJ. Effects of peripheral administration of LPS on the expression of immunoreactive interleukin-1 alpha, beta, and receptor antagonist in rat brain. Ann N Y Acad Sci. 1998; 840:128-38.

23. Roth J, Rummel C, Barth SW, Gerstberger R, Hübschle T. Molecular aspects of fever and hyperthermia. Neurol Clin. 2006; 24:421-39.

24. Dubé CM, Brewster AL, Baram TZ. Febrile seizures: mechanisms and relationship to epilepsy. Brain Dev. 2009; 31:366-71.

25. Heida JG, Boissé L, Pittman QJ. Lipopolysaccharide-induced febrile convulsions in the rat: short-term sequelae. Epilepsia. 2004; 45:1317-29.

26. Heida JG, Teskey GC, Pittman QJ. Febrile convulsions induced by the combination of lipopolysaccharide and low-dose kainic acid enhance seizure susceptibility, not epileptogenesis, in rats. Epilepsia. 2005; 46:1898-905.

27. Heida JG, Pittman QJ. Causal links between brain cytokines and experimental febrile convulsions in the rat. Epilepsia. 2005; 46:1906-13.

28. Dubé C, Chen K, Eghbal-Ahmadi M, Brunson K, Soltesz I, Baram TZ. Prolonged febrile seizures in the immature rat model enhance hippocampal excitability long term. Ann Neurol. 2000; 47:336-44.

29. Dubé C, Richichi C, Bender RA, Chung G, Litt B, Baram TZ. Temporal lobe epilepsy after experimental prolonged febrile seizures: prospective analysis. Brain. 2006; 129:911-22.

30. McCaughran JA, Schechter N. Experimental febrile convulsions: long-term effects of hyperthermia-induced convulsions in the developing rat. Epilepsia. 1982; 23:173-83.

31. El Radhi AS, Withana K, Banajeh S. Recurrence rate of febrile convulsion related to the degree of pyrexia during the first attack. Clin Pediatr (Phila). 1986; 25:311-3.

32. El Radhi AS. Lower degree of fever at the initial febrile convulsion is associated with increased risk of subsequent convulsions. Eur J Paediatr Neurol. 1998; 2:91-6.

33. Gordon, KE, Dooley JM, Wood EP, Bethune P. Is temperature regulation different in children susceptible to febrile seizures? Can J Neurol Sci. 2009; 36:192-5.

34. Tsuboi T. Epidemiology of febrile and afebrile convulsions in children in Japan. Neurology. 1984; 34:175-81.

35. al-Eissa YA. Febrile seizures: rate and risk factors of recurrence. J Child Neurol. 1995; 10:315-9.

36. Armstrong LE, Casa DJ, Millard-Stafford M, Moran DS, Pyne SW, Roberts WO. American College of Sports Medicine position stand. Exertional heat illness during training and competition. Med Sci Sports Exerc. 2007; 39:556-72.

37. Qu L, Liu X, Wu C, Leung LS. Hyperthermia decreases GABAergic synaptic transmission in hippocampal neurons of immature rats. Neurobiol Dis. 2007; 27:320-7.

38. Qu L, Leung LS. Mechanisms of hyperthermia-induced depression of GABAergic synaptic transmission in the immature rat hippocampus. J Neurochem. 2008; 106:2158-69.

39. Dubé C, Brunson KL, Eghbal-Ahmadi M, Gonzalez-Vega R, Baram TZ. Endogenous neuropeptide $\mathrm{Y}$ prevents recurrence of experimental febrile seizures by increasing seizure threshold. J Mol Neurosci. 2005; 25:275-84.

40. Pittman QJ, Naylor A, Poulin P, Disturnal J, Veale WL, Martin SM, et al. The role of vasopressin as an antipyretic in the ventral septal area and its possible involvement in convulsive disorders. Brain Res Bull. 1988: 20:887-92.

41. Allan SM, Parker LC, Collins B, Davies R, Luheshi GN, Rothwell NJ. Cortical cell death induced by IL- 1 is mediated via actions in the hypothalamus of the rat. Proc Natl Acad Sci USA. 2000; 97:5580-5.

42. Allan SM, Rothwell NJ. Cytokines and acute neurodegeneration. Nat Rev Neurosci. 2001; 2:734-44.

43. De Simoni MG, Perego C, Ravizza T, Moneta D, Conti M, Marchesi F, et al. Inflammatory cytokines and related genes are induced in the rat hippocampus by limbic status epilepticus. Eur J Neurosci. 2000; 12:2623-33.
44. Eriksson C, Tehranian R, Iverfeldt K, Winblad B, Schultzberg M. Increased expression of mRNA encoding interleukin-1beta and caspase-1, and the secreted isoform of interleukin-1 receptor antagonist in the rat brain following systemic kainic acid administration. J Neurosci Res. 2000; 60:266-79.

45. Jankowsky JL, Patterson PH. The role of cytokines and growth factors in seizures and their sequelae. Prog Neurobiol. 2001; 63:125-49.

46. Lehtimaki KA, Peltola J, Koskikallio E, Keranen T, Honkaniemi J. Expression of cytokines and cytokine receptors in the rat brain after kainic acid-induced seizures. Brain Res Mol Brain Res. 2003; 110:253-60.

47. Ichiyama T, Nishikawa M, Yoshitomi T, Hayashi T, Furukawa S. Tumor necrosis factor-alpha, interleukin-1 beta, and interleukin6 in cerebrospinal fluid from children with prolonged febrile seizures. Comparison with acute encephalitis/encephalopathy. Neurology. 1998; 50:407-11.

48. Lynch AM, Walsh C, Delaney A, Nolan Y, Campbell VA, Lynch MA. Lipopolysaccharide-induced increase in signalling in hippocampus is abrogated by IL-10--a role for IL-1 beta? J Neurochem. 2004; 88:635-46.

49. Viviani B, Bartesaghi S, Gardoni F, Vezzani A, Behrens MM, Bartfai $\mathrm{T}$, et al. Interleukin-1beta enhances NMDA receptormediated intracellular calcium increase through activation of the Src family of kinases. J Neurosci. 2003; 23:8692-700.

50. Hu S, Sheng WS, Ehrlich LC, Peterson PK, Chao CC. Cytokine effects on glutamate uptake by human astrocytes. Neuroimmunomodulation. 2000; 7:153-9.

51. Bezzi P, Domercq M, Brambilla L, Galli R, Schols D, De Clercq E, et al. CXCR4-activated astrocyte glutamate release via TNFalpha: amplification by microglia triggers neurotoxicity. Nat Neurosci. 2001; 4:702-10.

52. Casamenti F, Prosperi C, Scali C, Giovannelli L, Colivicchi MA, Faussone-Pellegrini MS, et al. Interleukin-1beta activates forebrain glial cells and increases nitric oxide production and cortical glutamate and GABA release in vivo: implications for Alzheimer's disease. Neuroscience. 1999; 91:831-42.

53. Wang S, Cheng Q, Malik S, Yang J. Interleukin-1beta inhibits gamma-aminobutyric acid type A $(\mathrm{GABA}(\mathrm{A}))$ receptor current in cultured hippocampal neurons. J Pharmacol Exp Ther. 2000; 292:497-504

54. Helminen M, Vesikari T. Increased interleukin-1 (IL-1) production from LPS-stimulated peripheral blood monocytes in children with febrile convulsions. Acta Paediatr Scand. 1990; 79:810-6.

55. Matsuo M, Sasaki K, Ichimaru $T$, Nakazato S, Hamasaki Y. Increased IL-1beta production from dsRNA-stimulated leukocytes in febrile seizures. Pediatr Neurol. 2006; 35:102-6.

56. Pociot F, Mølvig J, Wogensen L, Worsaae H, Nerup J. A TaqI polymorphism in the human interleukin-1 beta (IL-1 beta) gene correlates with IL-1 beta secretion in vitro. Eur J Clin Invest. $1992 ; 22: 396-402$.

57. Kira R, Torisu H, Takemoto M, Nomura A, Sakai Y, Sanefuji M, et al. Genetic susceptibility to simple febrile seizures: interleukin1 beta promoter polymorphisms are associated with sporadic cases. Neurosci Lett. 2005; 384:239-44.

58. Virta $M$, Hurme $M$, Helminen $M$. Increased frequency of interleukin-1beta $(-511)$ allele 2 in febrile seizures. Pediatr Neurol. 2002; 26:192-5.

59. Kanemoto K, Kawasaki J, Yuasa S, Kumaki T, Tomohiro O, Kaji R, et al. Increased frequency of interleukin-1beta-511T allele in patients with temporal lobe epilepsy, hippocampal sclerosis, and prolonged febrile convulsion. Epilepsia. 2003; 44:796-9.

60. Serdaroğlu G, Alpman A, Tosun A, Pehlivan S, Ozkinay F, Tekgül H, Gökben S. Febrile seizures: interleukin 1beta and interleukin1 receptor antagonist polymorphisms. Pediatr Neurol. 2009; 40:113-6.

61. Lahat E, Livne M, Barr J, Katz Y. Interleukin-1beta levels in serum and cerebrospinal fluid of children with febrile seizures. Pediatr Neurol. 1997; 17:34-6.

62. Tomoum HY, Badawy NM, Mostafa AA, Harb MY. Plasma interleukin-1beta levels in children with febrile seizures. J Child Neurol. 2007; 22:689-92. 
63. Haspolat S, Anlar B, Köse G, Coskun M, Yegin O. Interleukin1beta, interleukin-1 receptor antagonist levels in patients with subacute sclerosing panencephalitis and the effects of different treatment protocols. J Child Neurol. 2001; 16:417-20.

64. Riazi K, Galic MA, Kuzmiski JB, Ho W, Sharkey KA, Pittman QJ. Microglial activation and TNFalpha production mediate altered CNS excitability following peripheral inflammation. Proc Natl Acad Sci USA. 2008; 105:17151-6.

65. Konsman JP, Veeneman J, Combe C, Poole S, Luheshi GN, Dantzer R. Central nervous action of interleukin-1 mediates activation of limbic structures and behavioural depression in response to peripheral administration of bacterial lipopolysaccharide. Eur J Neurosci. 2008; 28:2499-510.

66. Rummel C, Inoue W, Sachot C, Poole S, Hübschle T, Luheshi GN. Selective contribution of interleukin-6 and leptin to brain inflammatory signals induced by systemic LPS injection in mice. J Comp Neurol. 2008; 511:373-95.

67. Hart Y. Rasmussen's encephalitis. Epileptic Disord. 2004; 6:133-44.

68. Hart YM, Cortez M, Andermann F, Hwang P, Fish DR, Dulac O, et al. Medical treatment of Rasmussen's syndrome (chronic encephalitis and epilepsy): effect of high-dose steroids or immunoglobulins in 19 patients. Neurology 1994; 44:1030-6.

69. Walter GF, Renella RR. Epstein-Barr virus in brain and Rasmussen's encephalitis. Lancet. 1989; 1:279-80.

70. Power C, Poland SD, Blume WT, Girvin JP, Rice GP. Cytomegalovirus and Rasmussen's encephalitis. Lancet. 1990; 336:1282-4.

71. Farrell MA, DeRosa MJ, Curran JG, Secor DL, Cornford ME, Comair YG, et al. Neuropathologic findings in cortical resections (including hemispherectomies) performed for the treatment of intractable childhood epilepsy. Acta Neuropathol. 1992; 83: 246-59.

72. O'Meara M, Ouvrier R. Viral encephalitis in children. Curr Opin Pediatr. 1996; 8: 11-5.

73. Panayiotopoulos CP, Michael M, Sanders S, Valeta T, Koutroumanidis M. Benign childhood focal epilepsies: assessment of established and newly recognized syndromes. Brain. 2008; 131:2264-86.

74. Scheffer IE, Harkin LA, Grinton BE, Dibbens LM, Turner SJ, Zielinski MA, et al. Temporal lobe epilepsy and GEFS+ phenotypes associated with SCN1B mutations. Brain. 2007; 130:100-9.

75. Harkin LA, McMahon JM, Iona X, Dibbens L, Pelekanos JT, Zuberi SM, et al. The spectrum of SCN1A-related infantile epileptic encephalopathies. Brain. 2007; 130:843-52.

76. Dubé C, Vezzani A, Behrens M, Bartfai T, Baram TZ. Interleukin1beta contributes to the generation of experimental febrile seizures. Ann Neurol. 2005; 57:152-5.

77. Gadomski AM, Permutt T, Stanton B. Correcting respiratory rate for the presence of fever. J Clin Epidemiol. 1994; 47:1043-9.

78. Taylor JA, Del Beccaro M, Done S, Winters W. Establishing clinically relevant standards for tachypnea in febrile children younger than 2 years. Arch Pediatr Adolesc Med. 1995; 149: 283-7.

79. Kaila K, Ransom B. 1998. Concept of pH and its importance in neurobiology. In: pH and Brain Function. Kaila K, Ransom B, editors. New York: Wiley-Liss; 1998. p. 3-10.

80. Jarolimek W, Misgeld U, Lux HD. Activity dependent alkaline and acid transients in guinea pig hippocampal slices. Brain Res. $1989 ; 505: 225-32$.

81. Schuchmann S, Vanhatalo S, Kaila K. Neurobiological and physiological mechanisms of fever-related epileptiform syndromes. Brain Dev. 2009; 31:378-82.

82. Schuchmann S, Schmitz D, Rivera C, Vanhatalo S, Salmen B, Mackie K, et al. Experimental febrile seizures are precipitated by a hyperthermia-induced respiratory alkalosis. Nat Med. 2006; 12:817-23

83. Schuchmann S, Tolner EA, Marshall P, Vanhatalo S, Kaila K. Pronounced increase in breathing rate in the "hair dryer model" of experimental febrile seizures. Epilepsia. 2008; 49:926-8.

84. Bocti C, Robitaille Y, Diadori P, Lortie A, Mercier C, Bouthillier A, et al. The pathological basis of temporal lobe epilepsy in childhood. Neurology. 2003; 60:191-5.
85. Germano IM, Zhang YF, Sperber EF, Moshé SL. Neuronal migration disorders increase susceptibility to hyperthermiainduced seizures in developing rats. Epilepsia. 1996; 37:902-10.

86. Scantlebury MH, Ouellet PL, Psarropoulou C, Carmant L. Freeze lesion-induced focal cortical dysplasia predisposes to atypical hyperthermic seizures in the immature rat. Epilepsia. 2004; 45: 592-600.

87. Scantlebury MH, Gibbs SA, Foadjo B, Lema P, Psarropoulou C, Carmant L. Febrile seizures in the predisposed brain: a new model of temporal lobe epilepsy. Ann Neurol. 2005; 58:41-9.

88. Gibbs SA, Scantlebury MH, Awad P, Lema P, Essouma JB, Parent $\mathrm{M}$, et al. Hippocampal atrophy and abnormal brain development following a prolonged hyperthermic seizure in the immature rat with a focal neocortical lesion. Neurobiol Dis. 2008; 32:176-82.

89. Vestergaard M, Pedersen CB, Sidenius P, Olsen J, Christensen J. The long-term risk of epilepsy after febrile seizures in susceptible subgroups. Am J Epidemiol. 2007; 165:911-8.

90. Camfield P, Camfield C, Gordon K, Dooley J. What types of epilepsy are preceded by febrile seizures? A population-based study of children. Dev Med Child Neurol. 1994; 36:887-92.

91. Tarkka R, Pääkkö E, Pyhtinen J, Uhari M, Rantala H. Febrile seizures and mesial temporal sclerosis: no association in a longterm follow-up study. Neurology. 2003; 60:215-8.

92. Pittau F, Bisulli F, Mai R, Fares JE, Vignatelli L, Labate A, et al. Prognostic factors in patients with mesial temporal lobe epilepsy. Epilepsia. 2009; 50 Suppl 1:41-4.

93. Kanemoto K, Takuji N, Kawasaki J, Kawai I. Characteristics and treatment of temporal lobe epilepsy with a history of complicated febrile convulsion. J Neurol Neurosurg Psychiatry. 1998; 64:245-8.

94. Schmidt D, Tsai JJ, Janz D. Febrile seizures in patients with complex partial seizures. Acta Neurol Scand. 1985; 72:68-71.

95. Janszky J, Schulz R, Ebner A. Clinical features and surgical outcome of medial temporal lobe epilepsy with a history of complex febrile convulsions. Epilepsy Res. 2003; 55:1-8.

96. Abou-Khalil B, Andermann E, Andermann F, Olivier A, Quesney LF. Temporal lobe epilepsy after prolonged febrile convulsions: excellent outcome after surgical treatment. Epilepsia. 1993; 34:878-83.

97. Kwak SE, Kim JE, Kim SC, Kwon OS, Choi SY, Kang TC. Hyperthermic seizure induces persistent alteration in excitability of the dentate gyrus in immature rats. Brain Res. 2008; 1216: $1-15$.

98. Ateş N, Akman O, Karson A. The effects of the immature rat model of febrile seizures on the occurrence of later generalized tonicclonic and absence epilepsy. Brain Res Dev Brain Res. 2005; 154:137-40.

99. Theodore WH, DeCarli C, Gaillard WD. Total cerebral volume is reduced in patients with localization-related epilepsy and a history of complex febrile seizures. Arch Neurol. 2003; 60: 250-2

100. Ellenberg JH, Nelson KB. Febrile seizures and later intellectual performance. Arch Neurol. 1978; 35:17-21

101. Chang YC, Guo NW, Huang CC, Wang ST, Tsai JJ. Neurocognitive attention and behavior outcome of school-age children with a history of febrile convulsions: a population study. Epilepsia. $2000 ; 41: 412-20$

102. Mesquita AR, Tavares HB, Silva R, Sousa N. Febrile convulsions in developing rats induce a hyperanxious phenotype later in life. Epilepsy Behav. 2006; 9:401-6.

103. Werboff J, Havlena J. Febrile convulsions in infant rats, and later behavior. Science. 1963; 142:684-5.

104. Kornelsen RA, Boon F, Leung LS, Cain DP. The effects of a single neonatally induced convulsion on spatial navigation, locomotor activity and convulsion susceptibility in the adult rat. Brain Res. 1996; 706:155-9.

105.Lemmens EM, Aendekerk B, Schijns OE, Blokland A, Beuls EA, Hoogland G. Long-term behavioral outcome after early-life hyperthermia-induced seizures. Epilepsy Behav. 2009; 14: 309-15.

106. Nealis JG, Rosman NP, De Piero TJ, Ouellette EM. Neurologic sequelae of experimental febrile convulsions. Neurology. 1978; $28: 246-50$. 
107. Chang YC, Huang AM, Kuo YM, Wang ST, Chang YY, Huang CC. Febrile seizures impair memory and cAMP response-element binding protein activation. Ann Neurol. 2003; 54:706-18.

108. Provenzale JM, Barboriak DP, VanLandingham K, MacFall J, Delong D, Lewis DV. Hippocampal MRI signal hyperintensity after febrile status epilepticus is predictive of subsequent mesial temporal sclerosis. AJR Am J Roentgenol. 2008; 190:976-83.

109. Hesdorffer DC, Chan S, Tian H, Allen Hauser W, Dayan P, Leary LD, et al. Are MRI-detected brain abnormalities associated with febrile seizure type? Epilepsia. 2008; 49:765-71.

110. Natsume J, Bernasconi N, Miyauchi M, Naiki M, Yokotsuka T, Sofue A, et al. Hippocampal volumes and diffusion-weighted image findings in children with prolonged febrile seizures. Acta Neurol Scand Suppl. 2007; 186:25-8.

111. Scott RC, King MD, Gadian DG, Neville BG, Connelly A. Hippocampal abnormalities after prolonged febrile convulsion: a longitudinal MRI study. Brain. 2003; 126:2551-7.

112. Auer T, Barsi P, Bone B, Angyalosi A, Aradi M, Szalay C, et al. History of simple febrile seizures is associated with hippocampal abnormalities in adults. Epilepsia. 2008; 49:1562-9.

113. Dubé C, Yu H, Nalcioglu O, Baram TZ. Serial MRI after experimental febrile seizures: altered T2 signal without neuronal death. Ann Neurol. 2004; 56:709-14.

114. Bender RA, Dubé C, Gonzalez-Vega R, Mina EW, Baram TZ. Mossy fiber plasticity and enhanced hippocampal excitability, without hippocampal cell loss or altered neurogenesis, in an animal model of prolonged febrile seizures. Hippocampus. 2003; 13:399-412.

115. Toth Z, Yan XX, Haftoglou S, Ribak CE, Baram TZ. Seizureinduced neuronal injury: vulnerability to febrile seizures in an immature rat model. J Neurosci. 1998; 18:4285-94.

116. Sendrowski K, Sobaniec W, Sobaniec-Lotowska ME, Artemowicz B. Topiramate as a neuroprotectant in the experimental model of febrile seizures. Adv Med Sci. 2007; 52 Suppl 1:161-5.

117.Lemmens EM, Lubbers T, Schijns OE, Beuls EA, Hoogland G. Gender differences in febrile seizure-induced proliferation and survival in the rat dentate gyrus. Epilepsia. 2005; 46:1603-12.

118. Lemmens EM, Schijns OE, Beuls EA, Hoogland G. Cytogenesis in the dentate gyrus after neonatal hyperthermia-induced seizures: what becomes of surviving cells? Epilepsia. 2008; 49:853-60.

119. Pape HC. Queer current and pacemaker: the hyperpolarizationactivated cation current in neurons. Annu Rev Physiol. 1996; 58: 299-327.
120. Siegelbaum SA. Presynaptic facilitation by hyperpolarizationactivated pacemaker channels. Nat Neurosci. 2000; 3:101-2.

121. Chen K, Aradi I, Thon N, Eghbal-Ahmadi M, Baram TZ, Soltesz I. Persistently modified h-channels after complex febrile seizures convert the seizure-induced enhancement of inhibition to hyperexcitability. Nat Med. 2001; 7:331-7.

122. Brewster A, Bender RA, Chen Y, Dubé C, Eghbal-Ahmadi M, Baram TZ. Developmental febrile seizures modulate hippocampal gene expression of hyperpolarization-activated channels in an isoform- and cell-specific manner. J Neurosci. 2002; 22:4591-9.

123. Brewster AL, Bernard JA, Gall CM, Baram TZ. Formation of heteromeric hyperpolarization-activated cyclic nucleotide-gated (HCN) channels in the hippocampus is regulated by developmental seizures. Neurobiol Dis. 2005; 19:200-7.

124. Kamal A, Notenboom RG, de Graan PN, Ramakers GM. Persistent changes in action potential broadening and the slow afterhyperpolarization in rat CA1 pyramidal cells after febrile seizures. Eur J Neurosci. 2006; 23:2230-4.

125. Richichi C, Brewster AL, Bender RA, Simeone TA, Zha Q, Yin HZ, et al. Mechanisms of seizure-induced 'transcriptional channelopathy' of hyperpolarization-activated cyclic nucleotide gated (HCN) channels. Neurobiol Dis. 2008; 29:297-305.

126. Chen K, Baram TZ, Soltesz I. Febrile seizures in the developing brain result in persistent modification of neuronal excitability in limbic circuits. Nat Med. 1999; 5:888-94.

127. Chen K, Ratzliff A, Hilgenberg L, Gulyás A, Freund TF, Smith M, et al. Long-term plasticity of endocannabinoid signaling induced by developmental febrile seizures. Neuron. 2003; 39:599-611.

128. González Ramírez M, Orozco Suárez S, Salgado Ceballos H, Feria Velasco A, Rocha L. Hyperthermia-induced seizures modify the $\mathrm{GABA}(\mathrm{A})$ and benzodiazepine receptor binding in immature rat brain. Cell Mol Neurobiol. 2007; 27:211-27.

129. Han Y, Qin J, Bu DF, Chang XZ, Yang ZX. Successive alterations of hippocampal gamma-aminobutyric acid $\mathrm{B}$ receptor subunits in a rat model of febrile seizure. Life Sci. 2006; 78:2944-52.

130. Tsai ML, Leung LS. Decrease of hippocampal GABA B receptormediated inhibition after hyperthermia-induced seizures in immature rats. Epilepsia. 2006; 47:277-87. 